\title{
THE EFFECT OF ORGANIZATIONAL CULTURE AND TRANSFORMATIONAL LEADERSHIP ON KNOWLEDGE SHARING: A STUDY IN BUMIGORA UNIVERSITY OF WEST NUSA TENGGARA, INDONESIA
}

\author{
Dayani Aprillia Dwi \\ Master's Study Program of Management, University of Mataram, Mataram, \\ West Nusa Tenggara, Indonesia \\ Asmony Thatok, Hermanto* \\ Department of Management, Faculty of Economics and Business, University of Mataram, \\ Mataram, West Nusa Tenggara, Indonesia \\ *E-mail: hermanto2307@gmail.com
}

\begin{abstract}
This study aims to explain and to examine the direct impact of organizational culture and transformational leadership on knowledge sharing among lecturers at Bumigora University of West Nusa Tenggara, Indonesia. This study uses Dennison's organizational culture theory and Bass Avolio's transformational leadership theory. A quantitative approach is applied where data are collected based on a survey method by using a Likert scale. The data analysis technique used in this study is Partial Least Square (PLS). The population of this research is all lecturers of Bumigora University are involved as the unit analysis of this research in which 112 lecturers are treated as research respondents, but only 100 questionnaires were eligible to be used as research data. The research indicates that there is a positive and significant direct effect of organizational culture on knowledge sharing and effect of transformational leadership on knowledge sharing. The result also demonstrates that organizational culture had a positive and significant direct effect on knowledge sharing. This shows that the stronger organizational culture, better the implementation of perceived knowledge sharing. In addition, transformational leadership has a positive and significant effect on knowledge sharing. That means the more effective transformational leadership, better the implementation of knowledge sharing with lecturers at Bumigora University.
\end{abstract}

\section{KEY WORDS}

Organizational, culture, transformational, leadership, knowledge sharing, lecturers, private university.

Knowledge Management (KM) as any process of creating, acquisition, transfer/sharing, storing, and reuse (Sangkala, 2007). Knowledge sharing is fundamental in the process of knowledge management (Khakpour, Ghahremani, and Pardakhtchi (2009). Other researchers also found that the process of knowledge sharing is at the core of successful knowledge management (Lumbantobing, 2011). Without sharing, the learning process and knowledge creation will be hampered. Without sharing, the scale of knowledge utilization will also very limited, because knowledge is only used by people or units in a limited. Knowledge sharing is also defined as the spread of ideas, information, expertise, and advice among individuals in organizations to solve problems, develop new ideas, or implement policies or procedures (Pulakos, Dorsey, \& Borman, 2003; Cummings, 2004; Wang \& Noe, 2010; in Liu \& Li, 2018). Nonaka \& Takeuchi (1995) identifies four possible modes: socialization, externalization, combination, and internalization. Knowledge sharing that occurs in organizations can be divided into two, namely tacit knowledge sharing (developed through experience and difficult to communicate) and explicit knowledge sharing (knowledge that can be learned and communicated easily, both in verbal and written).

Success or failure of knowledge management is very dependent on culture that can determine the ability of people, not only to create but also to share and effectively use their 
knowledge and transfer their tacit knowledge to explicit knowledge (Poul, Khanlarzadeh, and Samiei, 2016). Organizational culture is an important role that makes members of the organization to work together and share their knowledge (Li, 2018). Sharing and transferring knowledge within an organization is a more complex process compared to other processes. This is evidenced that organizational culture may have a natural resistance to sharing knowledge, so it is currently a concern for organizational leaders and senior managers (Khakpour, 2009). According to Khosravi (2013) in Jambak (2017) based on studies that have been done before, at each university shows that sharing knowledge in the academic world faces similar obstacles to those encountered in the business world. One of the obstacles is the weak organizational culture to share knowledge so that academic activities are still very individual.

Transformational leadership can be identified as an important factor in sharing knowledge, because leaders direct to improve behavior directed at organizational goals (Husseini \& Dosa, 2016). According to Bass and Avolio (1994) transformational leadership has four dimensions, including charisma, inspirational stimulation, intellectual stimulation, and individual consideration. Zheng, Wu, and Xie (2017) and Xia (2012) research results show that transformational leadership has a significant positive effect on knowledge sharing. It is assumed that transformational leadership can effectively facilitate the exchange of knowledge among followers ( $\mathrm{Li}, 2018)$. This is supported because the dimensions of transformational leadership are in line with knowledge management (Li, 2018). In addition, it was found that transformational leadership positively influenced leader-member exchanges, which led to an increase in knowledge sharing and increased followers trust in leaders (Lee, 2010; Li, 2014). According to Świgon (2017) the phenomenon of knowledge sharing is complex, but it is very interesting and important for future development in all fields, especially the academic environment. In addition, from previous research searches, it is very rare to share knowledge into dependent variables $(Y)$ or outcome variables. According to Sackmann and Friesl (2007) in Hermanto (2018) research on the influence of organizational culture on knowledge sharing has not been found, so there are still gaps.

Bumigora University has a lot of knowledge in the minds of its Human Resources, especially lecturers. Researchers conduct research at private universities because lecturers at private universities tend to want to move to rival lecturers at state universities. However, based on preliminary observations, it is known that in fact some lecturers still ignore sharing knowledge, especially with senior lecturers, as well as low levels of participation in forums or seminars and lack of initiative from lecturers to share knowledge with other lecturers who were not present at the meeting. The organizational culture at Bumigora University is Innovative and Integrity to Achieve Quality (IQ) which means innovative and integrity to achieve quality. If Bumigora University's organizational culture is related to the dimensions and indicators of organizational culture from various models (including Robbins, Schein, Dennison, Wallace, and Hofstede), Dennison's model is most suitable for measuring organizational culture at Bumigora University. In addition, transformational leadership adopted at Bumigora University is in accordance with the indicators of transformational leadership. Evidenced by the results of the initial questionnaire, that the leader is more inclined towards shared interests compared to self interests.

\section{LITERATURE REVIEW}

Organizational culture is a pattern that is created, discovered, or developed so that people can adjust to organizational life (Ivancevich, 2006). Dimensions of organizational culture according to Dennison (2009) include involvement (empowerment, team orientation, capability development), consistency (core values, agreement, coordination and integration), adaptability (creating change, customer focus, organizational learning), mission (strategic direction and intent, goals and objectives, vision).

Mustomi (2017) and Hermanto (2018) research results show that organizational culture has several positive significant effects on knowledge sharing. Therefore, it is important to explore the suitability of organizational culture for sharing knowledge as one of the most 
important knowledge management processes and the impact of several cultural attributes (trust, collaborative work environment, shared vision and management practices on sharing knowledge). Organizational culture an important role by enabling organizational members to work together and share their knowledge (Li, 2018). The existence of a supportive and teamoriented organizational culture can improve knowledge sharing in an organization (Borges, 2013). Organizations can create supportive culture and team oriented by creating organizational values that support teamwork and support each other. From a conducive organizational culture, it will share the culture of sharing Bumigora University lecturers.

$\mathrm{H}_{1}$ : Organizational culture impacts positively significant on knowledge sharing.

Transformational leadership is the process of influencing others to facilitate the achievement of relevant organizational goals (Ivancevich, 2006). Transformational leadership can be identified as an important factor in knowledge sharing, because leaders direct followers to improve behavior directed at the goal of improving performance and innovation for organizations (Husseini \& Dosa, 2016). Zheng, Wu, and Xie (2017), Irianto et al. (2019) and Xia (2012) research results show that transformational leadership has some significant positive effects on knowledge sharing. It is widely assumed that transformational leadership can effectively facilitate the exchange of knowledge among followers, but most investigations of the underlying mechanism are based on the perspective of social exchange (Li, 2018), so it is important for leaders to facilitate knowledge sharing among followers. Transformational leadership is more important in promoting knowledge sharing at the individual level. It has also been proven that transformational leadership is positively related to knowledge sharing. This is supported because the dimension of transformational leadership fits well with knowledge management (Li, 2018).

$\mathrm{H}_{2}$ : Organizational culture impacts positively significant on knowledge sharing.

\section{METHODS OF RESEARCH}

The method used in this research is quantitative research methods. Because positivism is the basis for quantitative research, the paradigm of this research is the positivism paradigm. A positivist paradigm is applied that emphasize on theoretical testing where data collected by using questionnaire survey and an in depth interview to get a valid and reliable result (Cooper \& Schindler, 2011). There are 112 lecturers are treated as research respondents, but only 100 questionnaires were eligible to be used as research data. Survey items were adapted from existing instruments used in past research and each respondent's perceptional answer is based on five score of Likert scale. Survey items were adapted from existing instruments used in past research and each respondent's perceptional answer is based on five score of Likert scale. To measure subject's perceptions of transformational leadership Bass and Avolio was employed. For the purpose of this study, four subscales were loaded together and used as a measure for transformational leadership (Charisma, Inspiration, Individualized Consideration, and Intellectual Stimulation). Measures assessing organizational culture were adapted from Denison that encompassed four functional dimensions: adaptability, consistency, involvement, and mission. The data analysis technique used in this study is Partial Least Square (PLS).

\section{RESULTS OF STUDY}

The lowest convergent validity based on PLS obtained by intellectual stimulation indicator of transformational leadership variable (0.703), and the highest scored by mission dimension of organizational culture variable (0.889).

Table 1 - Value of AVE and Alpha

\begin{tabular}{|c|c|c|}
\hline Variable & AVE & Cronbach's Alpha \\
\hline Knowledge Sharing & 0,619 & 0,938 \\
\hline Organizational Culture & 0,655 & 0,952 \\
\hline Transformational Leadership & 0,619 & 0,959 \\
\hline
\end{tabular}


Hypothesis testing and path coefficient of direct impact will be conducted in two variable latent where there are 2 direct relationships between exogenous variables and endogenous variables. The result shown by path coefficient value and critical value at significant value of alpha $=0.05$.

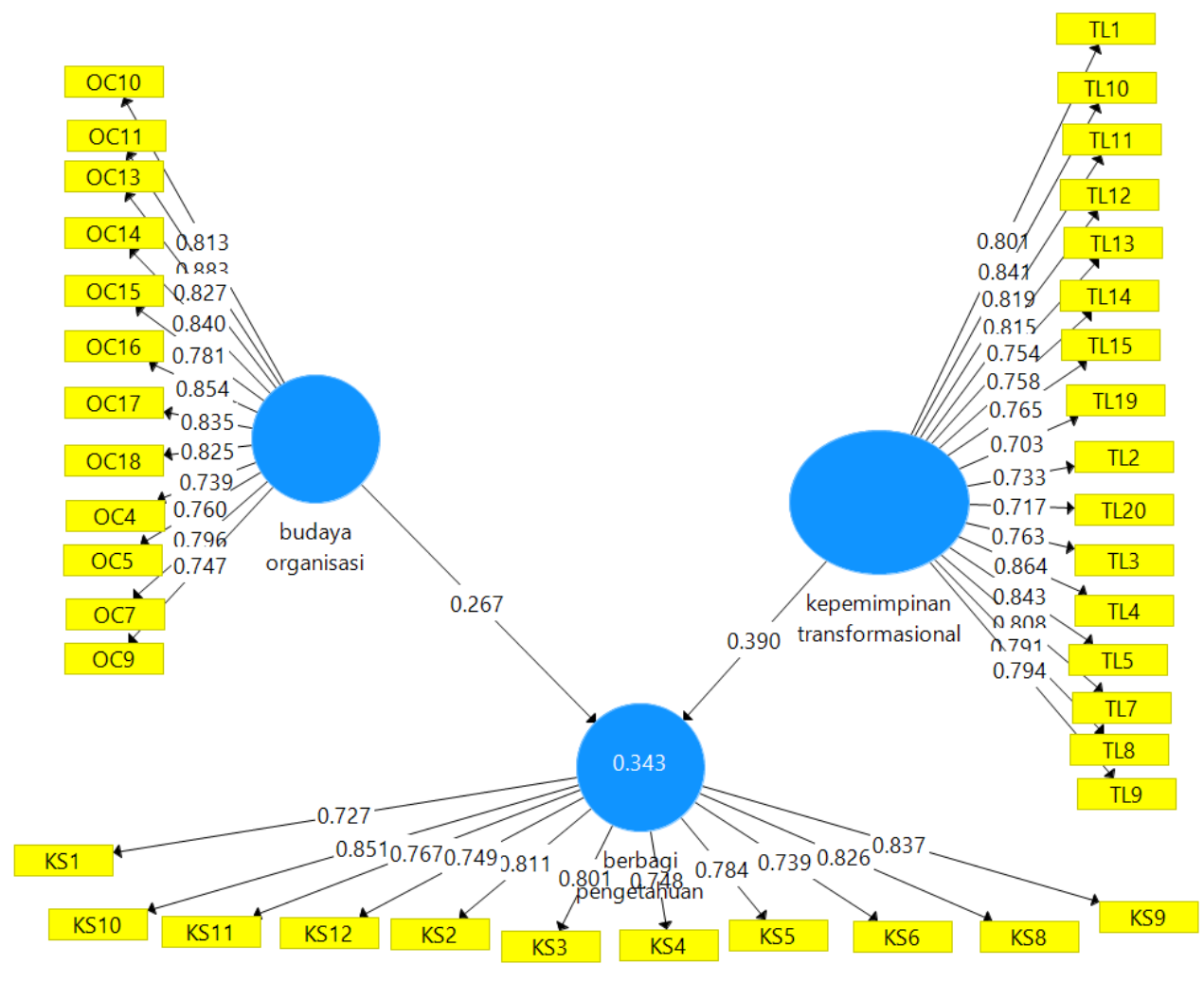

Table 2 - Path Coefficient of Direct Impact and Hypotheses Testing

\begin{tabular}{|c|c|c|c|c|}
\hline Hypothesis & Relationship & Path Coefficients & T-Statistic & Meaning \\
\hline H1 & $\mathrm{OC}(\mathrm{X} 1)->\mathrm{KS}(\mathrm{Y})$ & 0,267 & 2,522 & Significant/Accepted \\
\hline $\mathrm{H} 2$ & $\mathrm{TL}(\mathrm{X} 2)->\mathrm{KS}(\mathrm{Y})$ & 0,390 & 2,821 & Significant/Accepted \\
\hline
\end{tabular}

As hypotheses 1 and 2 predict, both organizational culture and transformational leadership are significantly related to knowledge sharing. This path coefficient shows an direct impact of independent variables (transformational leadership and organizational culture) on dependent variable (knowledge sharing).

Thus it can be seen that the stronger the organizational culture, the more it will increase the sharing of perceived knowledge, it is proven that this hypothesis supports the results of previous research by Islamy (2013) and Mustomi (2017) that organizational culture has a positive and significant effect on knowledge sharing.

\section{CONCLUSION}

Organizational culture and transformational leadership was found to fully impact knowledge sharing. This finding suggests that how well knowledge is managed is largely associated with how well cultural values are translated into value to the organization. Further, transformational leadership has a greater contribution to knowledge sharing than organizational culture variable. Organizational culture that provides conducive climate for conducting activities becomes important for individuals and organizations, so that the implementation of knowledge sharing can work effectively. Strong organizational culture makes the organization grow healthy, understand their rights and obligations and be able to continue to be creative for the betterment of the organization. 
This study not only strengthens the findings of previous studies which say that leaders are important factors in sharing knowledge to achieve organizational goals (Husseini \& Dosa, 2016), but also reveals that leadership factors are more important than cultural factors in sharing knowledge. If the results of previous studies find that transformational leaders who are wise in solving problems and paying special attention to lecturers will be more successful in improving knowledge sharing behavior (Mohammadi and Boroumand, 2016), this research complements that effective knowledge sharing is achieved if supported by cultural organizations with conducive organizational climate. This study also supports previous findings that leaders have the potential to influence increased knowledge sharing (Srivastava et al, 2006).

The results of this study develop and provide explanations focused on the effect of organizational culture and transformational leadership on knowledge sharing with Bumigora University lecturers. The results of this study theoretically support the theory expressed by Sangkala (2007) which states that knowledge sharing must be adapted to organizational culture. The results of this study have also been proven by several previous researchers, namely Islamy (2013) and Mustomi (2017) who stated that the stronger the organizational culture, the increasing the sharing of knowledge of Bumigora University lecturers. The results of this study have also been proven by several previous researchers, namely Husseini et al. (2016), Mohammadi et al. (2016), and Irianto et al. (2019) which states the more effective transformational leadership, the more knowledge sharing increases.

\section{REFERENCES}

1. Avolio, B. M. 1994. Improving Organizational Effectiveness through Transformational Leadership. Sage, Thousand Oaks.

2. Borges, R. 2013. Tacit Knowledge Sharing Between IT Workers. Management Research Review, Vol. 36 No. 1 pp. 89-108.

3. Boroumand, A. M. 2016. Transformational Leadership and Knowledge Sharing. International Journal of Information Science and Management, Vol. 14 No. 2 pp. 83-96.

4. Cooper and Schindler.2011. Business research methods $11^{\text {th }}$ edition. New York: McGraw Hill Companies.

5. Denison Consulting. 2009. Overview of the Reliability and Validity of the Denison Organizational Culture Survey. Denison Consulting Files

6. Hermanto. 2018. Pengaruh Tipe Budaya Organisasi Terhadap Perilaku Knowledge Sharing: Pendekatan Konsep. Jurnal Magister Manajemen, Vol. 7 No. 1 pp 20-31.

7. Islamy, F. J. 2013. Pengaruh Budaya Organisasi Terhadap Implementasi Knowledge Sharing Dosen Tetap Universitas Pendidikan Indonesia Bandung tahun 2013. Jurnal Indonesia Membangun, Vol. 14 No. 2.

8. Ivancevich, J. M. 2006. Perilaku and manajemen organisasi (7 ed.). Erlangga.

9. Jambak, M. I. 2017. Pengaruh Antesenden Perilaku Berbagi Pengetahuan Terhadap Keunggulan Kompetitif Organisasi. Konf. Nasional Riset Manajemen X, Vol. 14 No. 2.

10. Khakpour, A. M. G. 2009. The Relationship Between Organizational Culture And Knowledge Management (Cultural Barriers And Challenges Of Knowledge Sharing). Journal of Knowledge Economy \& Knowledge Management Vol. 4 pp. 43-58.

11. Lee, P. G. 2010, Leadership and trust: their effect on knowledge sharing and team performance. Management Learn Vol. 41 pp. 473-491.

12. Li, G. S. 2014. Differentiated Transformational Leadership And Knowledge Sharing: A Cross-Level Investigation. Eur. Management Vol. 32 pp. 554-563.

13. Li, H. L. 2018. Linking Transformational Leadership and Knowledge Sharing: The Mediating Roles of Perceived Team Goal Commitment and Perceived Team Identification". Frontiers in Psychology Vol. 9 pp. 1-10.

14. Lumbantobing, P. 2011. Manajemen Knowledge Sharing Berbasis Komunitas. Bandung: Knowledge Management Society Indonesia.

15. Mustomi, D. 2017. Pengaruh Budaya Organisasi and Peran Kepemimpinan terhadap Knowledge Sharing. Widya Cipta Vol. 1 No. 2 pp. 118-126. 
16. Poul, S. K., Khanlarzadeh F., \& Samiei V. 2016. The Impact Of Organizational Culture On Knowledge Sharing. Faculty of Business Economics and Entrepreneurship Vol. 3 No. 4 pp. 9-24.

17. Sangkala. (2007). Knowledge Management, Jakarta: Raja Grafindo Persada.

18. Sawsan J, Husseini \& Dosa T. A. 2016. The Effects Of Transformational Leadership On Process Innovation Through Knowledge Sharing. World Academy of Science, Enginerring and Technology International Journal of Economics and Management Engineering Vol. 10 No. 8.

19. Srivastava, A., Bartol, K.M. and Locke, E.A. 2006. Empowering Leadership In Management Teams: Effects On Knowledge Sharing, Efficacy, And Performance, Academy of Management Journal, Vol. 49 No. 6 pp. 1239-1251.

20. Sudibjo, Irianto S. and Niko. 2019. Leadership and Self-Efficacy (Teacher's Knowledge Sharing Behaviour from Transformational Leadership and Self-Efficacy's Perspective). Jurnal Ilmiah, Vol. 15 No. 2 pp. 255 - 269.

21. Świgoń, M. 2017. Knowledge sharing practices in informal scholarly communication amongst academics in Poland. Malaysian Journal of Library \& Information Science, Vol. 22 No. 2 pp. 101-115.

22. Xia, L. \& Ya, S. 2012. Study on Knowledge Sharing Behavior Engineering". Systems Engineering Procedia Vol. 4 pp. 468-476.

23. Zheng J., Wu G., \& Xie H. 2017. Impacts of Leadership on Project-Based Organizational Innovation Performance: The Mediator of Knowledge Sharing and Moderator of Social Capital". Journal Sustainability, Vol. 9 pp. 1-22. 